\title{
Oleiphilaceae fam. nov., to include Oleiphilus messinensis gen. nov., sp. nov., a novel marine bacterium that obligately utilizes hydrocarbons
}

1 Division of Microbiology, GBF-German Research Centre for Biotechnology, Mascheroder Weg 1, 38124 Braunschweig, Germany

2 Istituto Sperimentale Talassografico, CNR Consiglio Nazionale Ricerche, Spianata Santa Raineri 86, 98122 Messina, Italy

\author{
Peter N. Golyshin, ${ }^{1}$ Tatiana N. Chernikova, ${ }^{1}$ Wolf-Rainer Abraham, \\ Heinrich Lünsdorf, ${ }^{1}$ Kenneth N. Timmis ${ }^{1}$ and Michail M. Yakimov ${ }^{2}$ \\ Author for correspondence: Peter N. Golyshin. Tel: +49 531618 1498. Fax: +495316181411. \\ e-mail:pgo@gbf.de
}

\begin{abstract}
A bacterial isolate, ME102 ${ }^{\top}$, was obtained from an $n$-hexadecane enrichment culture of seawater/sediment samples collected in the harbour of Messina (Italy). This Gram-negative, aerobic, motile, rod-shaped bacterium used a narrow spectrum of organic compounds, including aliphatic hydrocarbons, alkanoates and alkanoles, as carbon and energy sources. None of the sugars, organic acids or amino acids tested was used. During cultivation on $n$-alkanes as the sole source of carbon and energy, the cells formed a biofilm on the surface of the alkane droplets. Large-scale (sometimes $>50 \%$ of the cell mass) intracellular accumulation of alkanoates occurred in cells adsorbed on the alkane surface and under nitrogen-limiting conditions. 16S rRNA gene sequence analysis showed that this isolate represents a distinct lineage in the $\gamma$-Proteobacteria and has about $91 \%$ sequence identity to members of Marinobacter and Alcanivorax, the closest genera. Four different types of polar lipid could be detected, phosphatidyl glycerol, phosphatidyl ethylamine, phosphatidyl dimethylethylamine and lipids belonging to an unknown type of phospholipid ( $\mathrm{m} / \mathrm{z}$ between 861 and 879). The principal fatty acids in the polar lipid fatty acid profile were 16:0 and 16:1. The putative gene encoding the key enzyme of alkane catabolism, alkane hydroxylase (AlkB), has been cloned. The protein sequence of the putative AlkB of the isolate ME102 ${ }^{\mathrm{T}}$ was related to the AlkB of Pseudomonas oleovorans and Alcanivorax borkumensis, showing about $60 \%$ sequence identity. On the basis of physiological studies and taking into account the distant phylogenetic position of isolate $\mathrm{ME}^{102}{ }^{\top}$ relative to previously described organisms, a novel genus and species is proposed, Oleiphilus messinensis gen. nov., sp. nov., within a new family, Oleiphilaceae

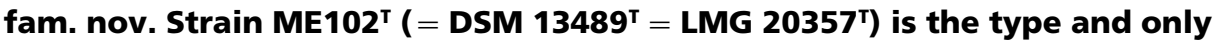
strain of 0 . messinensis.
\end{abstract}

Keywords: $n$-alkane, marine, hydrocarbonoclastic, $\gamma$-Proteobacteria

\section{INTRODUCTION}

Petroleum oil is a major source of energy that sustains modern society, the principal feedstock of the petro-

Abbreviations: CID, collision-induced dissociation; FAB-MS, fast-atombombardment mass spectrometry; GPA, glycerophosphoric acid; PFGE, pulsed field gel electrophoresis; PLFA, polar lipid fatty acid.

The GenBank/EMBL/DDBJ accession numbers for the 16S rRNA gene sequence and a fragment of the putative alkB gene sequence of Oleiphilus messinensis ME102 ${ }^{\top}$ are respectively AJ295154 and AJ295155. chemical industry and a serious environmental pollutant. Although all incidents of pollution by oil have environmental consequences, pollution of the sea and coastlines is particularly problematic, in both its scale and the severity of its ecological perturbations. The sustainable use of oil as a source of energy and chemicals urgently requires the development and implementation of new measures to reduce oil pollution of marine and coastal systems and its environmental impact. The latter requires a basic understanding of the fate of oil in such systems and of the parameters that govern this fate. 
During the last few years, efforts to isolate indigenous microbes by extinction dilution on medium containing only seawater and hydrocarbon substrates have yielded taxonomically new, physiologically novel, oildegrading marine bacteria from different sites all over the world (Button et al., 1998; Dyksterhouse et al., 1995; Hedlund et al., 1999; Yakimov et al., 1998). One of those, Alcanivorax sp., has been isolated from the Atlantic Ocean, the Mediterranean Sea, the North Sea, the Sea of Japan, the South China Sea and Antarctic waters (as shown by search results through EMBL/ GenBank databases); this bacterium, and probably others, seems to be cosmopolitan. Such bacteria exhibit highly restricted substrate profiles, essentially being able to use only petroleum hydrocarbons as carbon and energy sources. Significantly, these hydrocarbonoclastic bacteria are found in small numbers in unpolluted waters, but in high abundance in oilpolluted waters (Harayama et al., 1999). This indicates that they may play a crucial role in the natural cleansing of oil-polluted marine systems and implies that they could constitute the basis of novel biotechnology strategies to accelerate the environmental repair process. Since such organisms are likely to be limiting in unpolluted waters, this work was initiated with the isolation of oil-degraders from a constantly polluted ecosystem, seawater and sediments in the harbour of Messina (Italy). Results are presented of the phenotypic and phylogenetic analysis of one such

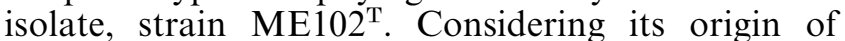
isolation and its ability to degrade aliphatic hydrocarbons, the name Oleiphilus messinensis gen. nov., sp. nov., is proposed and strain ME102 $2^{\mathrm{T}}$ (= DSM $13489^{\mathrm{T}}$ $=\mathrm{LMG} 20357^{\mathrm{T}}$ ) is designated the type strain. A novel family, Oleiphilaceae fam. nov., is proposed to accommodate $O$. messinensis.

\section{METHODS}

Bacterial strain. Isolate $\mathrm{ME} 102^{\mathrm{T}}$ was obtained from seawater/sediment samples collected in the harbour of Messina (Sicily, Italy) from a depth of about $8 \mathrm{~m}$, using enrichment culture with $n$-hexadecane (Fluka) as sole carbon source in synthetic seawater medium 1 (SM1) (Yakimov et al., 1998). The water/sediment sample (about 1 1) was filtered through a sterile nylon membrane filter $(0 \cdot 2 \mu \mathrm{m}$ pore diameter) covered with a glass-wool pre-filter. Both pre-filter and filter were sectioned in four pieces and one section was placed into a $50 \mathrm{ml}$ Falcon polypropylene tube containing $20 \mathrm{ml} \mathrm{ONR7a}$ (Dyksterhouse et al., 1995), supplemented with $1.5 \%(\mathrm{v} / \mathrm{v}) n$-hexadecane, and incubated at room temperature for 1 week. The resulting mixed culture was plated onto solid SM1 medium supplemented with the same carbon source and single colonies were isolated. Strain ME102 ${ }^{\mathrm{T}}$ was selected from a number of Gram-negative isolates (Table 1) for further studies.

Growth conditions. The bacterial strain was cultivated aerobically in media ONR7a and SM1 supplemented with $1.5 \%(\mathrm{v} / \mathrm{v}) n$-hexadecane. Bacto agar (Difco) $\left(15 \mathrm{~g} \mathrm{l}^{-1}\right)$ was added for the preparation of solid medium. Cell growth was monitored as cell dry weight as described previously (Passeri et al., 1992).
Phenotypic analysis. For all phenotypic tests, cultures were pre-grown in medium ONR7a, supplemented with $n$-hexadecane. Routine tests [Gram stain and amylase, oxidase, catalase, lipase (Tweenase), agarase and gelatinase activities] were carried out as described by Smibert \& Krieg (1981). Arginine dihydrolase, lysine decarboxylase, urease and ornithine decarboxylase activities, nitrate reduction and accumulation of poly- $\beta$-hydroxybutyrate were determined using the techniques for marine bacteria (Baumann \& Baumann, 1981). Utilization of carbon sources was tested in ONR7a medium supplemented with various compounds (listed in Table 2 and below) at concentrations of $25 \mathrm{mM}$. Sugars and related compounds: L-arabinose, fructose, sucrose, L-sorbitol, L- and D-glucose, glucose 1-phosphate, glucose 6-phosphate, L-maltose, D-xylose, D-mannitol, lactose, cellobiose, D-galactose, mannose, L-fucose, gentiobiose, myo-inositol, lactulose, D-melibiose, methyl $\beta$-Dglucoside, D-psicose, raffinose, L-rhamnose, D-sorbitol, Dtrehalose, turanose, xylitol, cyclodextrin, dextrin, inosine, uridine, thymidine and glycogen. Organic acids and their salts: acetic acid, cis-acetic acid, aminobutyric acid, benzoate, citric acid, formic acid, D-galactonic acid lactone, Dgalacturonic acid, D-gluconic acid, D-glucosaminic acid, Dglucuronic acid, $\alpha$-hydroxybutyric acid, $\beta$-hydroxybutyric acid, $\gamma$-hydroxybutyric acid, $p$-hydroxyphenylacetic acid, itaconic acid, $\alpha$-ketobutyric acid, $\alpha$-ketoglutaric acid, $\alpha$ ketovaleric acid, DL-lactic acid, malonic acid, propionic acid, L-pyroglutamic acid, pyruvate, methyl pyruvate, quinic acid, D-saccharic acid, sebacic acid, succinic acid, monomethyl succinate, bromosuccinic acid, succinamic acid and urocanic acid. Amino acids: alaninamide, D-alanine, Lalanyl glycine, L-asparagine, L-aspartic acid, DL-carnitine, glucuronamide, L-glutamic acid, glycyl L-aspartic acid, glycyl L-glutamic acid, L-histidine, hydroxy L-proline, Lleucine, L-ornithine, L-phenylalanine, L-proline, D-serine, L-serine, L-threonine, putrescine and phenylethylamine. Alcohols: 2-aminoethanol, 2,3-butanediol, glycerol, L- $\alpha$ glycerol phosphate, adonitol, D-arabitol and $i$-erythritol. Alkanes and derivatives: all $n$-alkanes with fatty chains between $\mathrm{C}_{8}$ and $\mathrm{C}_{24}$, as well as terminally monohydroxylated derivatives and fatty acids with the same fatty chain length. Others: Tweens 40 and 80, $N$-acetyl-Dgalactosamine and $N$-acetyl-D-glucosamine. Growth was estimated, as described above, after incubation for $48 \mathrm{~h}$.

Effects of salinity and temperature on growth were also examined. To determine the salinity range for growth, ONR7a medium supplemented with $n$-hexadecane was prepared with various concentrations of $\mathrm{NaCl}(0.06-$ $12.00 \%, \mathrm{w} / \mathrm{v})$. The temperature range for growth was determined by incubation of cultures in the same medium at $4,10,15,20,25,30,37$ and $45^{\circ} \mathrm{C}$.

Electron microscopy. Cells were grown exponentially in a biphasic liquid medium. Sediments from both phases were fixed in $2.5 \%(\mathrm{v} / \mathrm{v})$ glutardialdehyde, buffered in PBS $(8 \mathrm{~g}$ $\mathrm{NaCl}^{-1}, 2 \mathrm{~g} \mathrm{KCl}^{-1}, 1.44 \mathrm{~g} \mathrm{Na}_{2} \mathrm{HPO}_{4} 1^{-1}, 0.24 \mathrm{~g} \mathrm{KH}_{2} \mathrm{PO}_{4} 1^{-1}$, $\mathrm{pH} 7 \cdot 4$ ) and processed for shadow-casting and embedding as described recently (Golyshina et al., 2000).

Polar lipid fatty acid (PLFA) analysis and analysis of the crystalline inclusions. Lipids were extracted using a modified Bligh-Dyer procedure (Bligh \& Dyer, 1959; Vancanneyt et al., 1996). Intracellular crystalline inclusions were extracted with chloroform from cells that were collected from the agar surface and pre-washed with hot acetone. Later, fatty acid methyl esters were generated and analysed by GC, as described previously (Vancanneyt et al., 1996). All values for 
Table 1. Isolates obtained from seawater sediment enriched with $n$-hexadecane

\begin{tabular}{|llc|}
\hline Isolate & Closest neighbour(s) (16S rDNA accession no.) & $\begin{array}{c}\text { 16S rDNA sequence } \\
\text { identity (\%) }\end{array}$ \\
& & $96 \cdot 3$ \\
ME101 & Oceanospirillum kriegii (AB006767) & $91 \cdot 1$ \\
ME102 & Marinobacter sp. CAB (U61848) & $91 \cdot 1$ \\
& Marinobacter aquaeolei (AJ000726) & $91 \cdot 1$ \\
ME103 & Marinobacter hydrocarbonoclasticus (Y16735) & $100 \cdot 0$ \\
ME104 & Alcanivorax borkumensis (Y12579) & $97 \cdot 0$ \\
ME105 & Fundibacter jadensis (AJ001150) & $97 \cdot 3$ \\
ME106 & Alcanivorax borkumensis (Y12579) & $100 \cdot 0$ \\
ME109 & Marinobacter sp. PCOB-2 (AJ000647) & $99 \cdot 3$ \\
ME111 & Alteromonas macleodii (Y18228) & $99 \cdot 7$ \\
ME112 & Alcanivorax borkumensis (Y12579) & $100 \cdot 0$ \\
& Fundibacter jadensis (AJ001150) & $99 \cdot 5$ \\
\end{tabular}

Table 2. Key phenotypic characteristics of strain $M E 102^{\top}$ and phylogenetically related marine bacteria from the $\gamma$-Proteobacteria

All taxa have typical Gram-negative cell wall profiles and rod morphology and are positive for nitrate reduction to nitrite, oxidase test (Kovacs) and utilization of hexadecane. All taxa are negative for growth at $4{ }^{\circ} \mathrm{C}$ and accumulation of poly- $\beta$ hydroxybutyrate. Data for Marinobacter hydrocarbonoclasticus and Alcanivorax borkumensis were respectively taken from Gauthier et al. (1992) and Yakimov et al. (1998).

\begin{tabular}{|c|c|c|c|}
\hline Characteristic & $\begin{array}{c}\text { Marinobacter } \\
\text { hydrocarbonoclasticus }\end{array}$ & $\begin{array}{l}\text { Alcanivorax } \\
\text { borkumensis }\end{array}$ & Strain ME102 \\
\hline Number and arrangement of flagella & 1, Polar or none & None & 1, Polar \\
\hline Optimum temperature $\left({ }^{\circ} \mathrm{C}\right)$ for growth & 32 & $20-30$ & $25-30$ \\
\hline Growth at $45^{\circ} \mathrm{C}$ & + & - & - \\
\hline \multicolumn{4}{|l|}{$\mathrm{NaCl}$ concentration $(\%)$ for growth: } \\
\hline Optimum & $3-6$ & $3-10$ & $2-5$ \\
\hline Maximum & 20 & $12 \cdot 5$ & 10 \\
\hline \multicolumn{4}{|l|}{ Utilization as sole carbon source: } \\
\hline Succinate & + & - & - \\
\hline L-Glutamate & + & - & - \\
\hline p-Hydroxybenzoate & + & - & - \\
\hline DNA G $+\mathrm{C}$ content $(\mathrm{mol} \%)$ & $52 \cdot 7$ & $53 \cdot 4$ & $49 \cdot 0$ \\
\hline
\end{tabular}

the PLFA composition of the novel isolate were means of GC data obtained from three independent series of PLFA isolations from the cells (or crystalline inclusions) and were given as percentages of the total amount of fatty acids recovered.

Fast-atom-bombardment mass spectrometry (FAB-MS) and tandem mass spectrometry. FAB-MS in the negative mode was performed on the first of two mass spectrometers of a tandem high-resolution instrument of E1B1E2B2 configuration (JMS-HX/HX110A; JEOL) at $10 \mathrm{kV}$ accelerating voltage. Resolution was set to $1: 1500$. The JEOL FAB gun was operated at $6 \mathrm{kV}$ with xenon as the FAB gas. A mixture of triethanolamine and tetramethylurea (Japanese matrix) was used as matrix. Negative daughter ion spectra were recorded using all four sectors of the tandem mass spectrometer. High-energy collision-induced dissociation (CID) took place in the third field-free region. Helium served as the collision gas at a pressure sufficient to reduce the precursor ion signal to $30 \%$ of the original value. The collision cell was operated at ground potential. Resolution of MS2 was set to 1/1000. FAB-CID spectra (linked scans of MS2 at constant $\mathrm{B} / \mathrm{E}$ ratio) were recorded at $300 \mathrm{~Hz}$ filtering with a JEOL DA 7000 data system.

With the aid of CID-MS, most compounds were elucidated. Diagnostically important fragments arose by cleavage of the phosphatidyl polar head group bond. In phospholipids, such as phosphatidyl glycerol, cleavages that are characteristic of the polar head group are known to occur in the negative and positive FAB modes (Heller et al., 1988). The resulting ions of such a process in phospholipids have the structures of glycerophosphoric acids (GPAs) and can be observed in the normal FAB as well as in the CID spectra. 
Additional CID experiments of the GPA anions allowed identification of these fatty acids (Murphy \& Harrison, 1994). CID of the (M-H) ${ }^{-}$ions from these GPAs yielded abundant carboxylate anions from both the $s n-1$ and $s n-2$ positions, thus allowing identification of the fatty acids attached to the different GPAs. In addition, neutral losses of the $s n-2$ and $s n-1$ substituents as free carboxylic acids, as well as loss of each fatty acyl group as a substituted ketene, were detected. Furthermore, the positions of fatty acids on the glycerol backbone were determined. For the fatty acid positioned at $s n-2$, the neutral loss as free fatty acid and as substituted ketene was more frequent than for that at $s n-1$ (Murphy \& Harrison, 1994). With this method, the structure of the GPA anions and, hence, phospholipid structures were identified (Abraham et al., 1997).

$\mathbf{G}+\mathbf{C}$ contents. The $\mathrm{G}+\mathrm{C}$ contents of the isolates were determined using the HPLC method described previously (Mesbah et al., 1989; Tamaoka \& Komagata, 1984). Purified non-methylated lambda phage DNA (Sigma) was used as a standard.

Genome format. Pulsed field gel electrophoresis (PFGE) of genomic DNA endonuclease digests generated by $A s c \mathrm{I}$, PacI, PmeI and SfiI (New England Biolabs) was performed with the Gene Navigator electrophoresis device (Pharmacia) with switch times ramped between 2 and $64 \mathrm{~s}$ at $6 \mathrm{~V} \mathrm{~cm}^{-1}$ (Shizuya et al., 1992). To obtain plasmids, cells of $\mathrm{ME} 102^{\mathrm{T}}$ from 11 culture were extracted using the Large Construct kit (Qiagen). DNA extracts obtained were later analysed by gel electrophoresis.

16S rRNA gene sequence determination and analysis of phylogenetic relationships. Total genomic DNA was isolated from $20 \mathrm{ml}$ late exponential phase cells grown in SM1 medium, supplemented with $1.5 \%(\mathrm{v} / \mathrm{v})$ hexadecane, using the CTAB miniprep protocol for bacterial genomic DNA preparations (Wilson, 1987). PCR amplification of the 16S rRNA genes was obtained using the forward primer $16 \mathrm{~F} 27$ (5'-AGAGTTTGATCMTGGCTCAG-3') and reverse primer 16R1492 (5'-TACGGYTACCTTGTTACGACTT$\left.3^{\prime}\right)$. Direct sequence determination of the PCR-amplified DNA was carried out using an automated DNA sequencer and Taq cycle-sequencing reactions according to the protocols of the manufacturer (Perkin-Elmer Applied Biosystems). The EMBL/GenBank/DDBJ accession numbers of the partial 16S rDNA sequences of a number of isolates obtained from the $n$-alkane enrichment are AJ302699-AJ302708.

Analysis of the sequences obtained was performed using SIMILARITY_MATRIX version 1.1, SEQUENCE_MATCH version 2.7 and SEQUENCE_ALIGN version 1.7 from the RDP (Maidak et al., 1997) and BLAST (Altschul et al., 1997). These analyses were used to estimate the degree of similarity to other 16S rRNA gene sequences. Nucleotide sequences were further aligned manually to $16 \mathrm{~S}$ rRNA sequence data from the RDP based on primary and secondary structure considerations using Se-Al sequence alignment editor version 1.0 alpha 1 (Rambaut, 1996). Positions (in the Escherichia coli numbering system) 70-100, 181-219, 447-487, 1004-1036, 1133-1141 and 1446-1456, as well as deleted and unknown positions, were eliminated for the comparison of sequences according to Anzai et al. (2000). Further phylogenetic analyses were restricted to nucleotide positions that were unambiguously alignable in all sequences. Names of reference organisms (accession numbers in parentheses) were as follows: 'Aeromarinobacter lutaoensis' CCRC 17087
(AF288157); Aeromonas hydrophila subsp. hydrophila ATCC $7966^{\mathrm{T}}$ (X60404); Alcanivorax borkumensis DSM $11573^{\mathrm{T}}$ (Y12579); Cardiobacterium hominis ATCC $15826^{\mathrm{T}}$ (M35014); Colwellia maris JCM 10085 ${ }^{\mathrm{T}}$ (AB002630); Ectothiorhodospira shaposhnikovii $\mathrm{BN} 9512^{\mathrm{T}} \quad$ (X93478); Escherichia coli MG1655 (U00006); Haemophilus influenzae ATCC 33391 ${ }^{\mathrm{T}}$ (M35019); Legionella pneumophila subsp. pneumophila ATCC $33152^{\mathrm{T}}$ (M59157); Marinobacter hydrocarbonoclasticus ATCC 27132 (AB019148); Marinomonas vaga ATCC $27119^{\mathrm{T}}$ (X67025); Methylomonas methanica ATCC $35067^{\mathrm{T}}$ (L20840); Microbulbifer hydrolyticus ATCC 700072 ${ }^{\mathrm{T}}$ (AF055269); Neptunomonas naphthovorans ATCC $700637^{\mathrm{T}}$ (AF053734); Oceanospirillum maris subsp. maris ATCC $27509^{\mathrm{T}}$ (AB006771); Oceanospirillum linum ATCC $11336^{\mathrm{T}}$ (M22365); Pirellula marina ATCC 49069 ${ }^{\mathrm{T}}$ X62912; Pseudomonas aeruginosa LMG 1242 ${ }^{\mathrm{T}}$ (Z76651); Pseudomonas elongata ATCC 10144 ${ }^{\mathrm{T}}$ (AB021368); Pseudomonas halophila DSM 3050 ${ }^{\mathrm{T}}$ (AB021383); Pseudomonas iners IAM $1419^{\mathrm{T}}$ (AB021408); Pseudomonas putida ATCC 11250 (AF095892); Thiocapsa roseopersicina DSM $217^{\mathrm{T}}$ (Y12364); unidentified $\gamma$-proteobacterium MBIC3958 (AB020600); Vibrio cholerae ATCC $14035^{\mathrm{T}}$ (Z21856); and Xanthomonas campestris ATCC $33913^{\mathrm{T}}$ (X95917). These selected organisms represented type species (if available) of validly published species, genera and families (Anzai et al., 2000). To make multiple bootstrapped datasets out of the data, the alignment was exported as a PHYLIP 3.5 interleaved file type to run the SEQBOOT program. Phylogenetic analyses using parsimony DNAPARS and neighbour-joining NEIGHBOR methods were performed. Random input order of sequences, single jumbling and the global rearrangement option were used to avoid potential bias introduced by the order of sequence addition. Least-squares distance matrix analyses, based on evolutionary distances and NEIGHBOR, were estimated from similarity values using DNADIST maximumlikelihood analysis with the multiple datasets option. The resulting tree files were analysed using the program CONSENSE to provide confidence estimates for phylogenetic tree topologies and to make a majority rule consensus tree. All phylogenetic programs used were from PHYLIP version $3.573 \mathrm{c}$ (Felsenstein, 1993).

Cloning of the putative alkB gene. The chromosomal DNA of isolate ME102 ${ }^{\mathrm{T}}$ was amplified with oligonucleotides under conditions described by Smits et al. (1999). The PCR product was cloned into the pCR $2 \cdot 1$ vector (Invitrogen) and sequenced with standard primers (T7 and rM13). Relevant protein sequences and the deduced putative AlkB protein sequence from strain ME102 ${ }^{\mathrm{T}}$ were aligned manually using $\mathrm{Se}-\mathrm{Al}$ sequence alignment editor version 1.0 alpha 1 (Rambaut, 1996). Evolutionary distances of the proteins based on maximum likelihood were calculated using the PROTDIST program and the dendrogram depicting phylogenetic relationships was derived using the FITCH program (Fitch-Margoliash method, version 3.572c) with random input order of sequences and the global rearrangement option (Felsenstein, 1993). The EMBL/GenBank/DDBJ accession number of the fragment of the putative alkane hydroxylase gene sequence is AJ295155.

\section{RESULTS}

\section{Isolates from seawater alkane enrichment}

Single colonies of micro-organisms (mainly small, $0.3-1.5 \mathrm{~mm}$ in diameter, flat and transparent) appeared after 1 week incubation of dilutions plated from the 

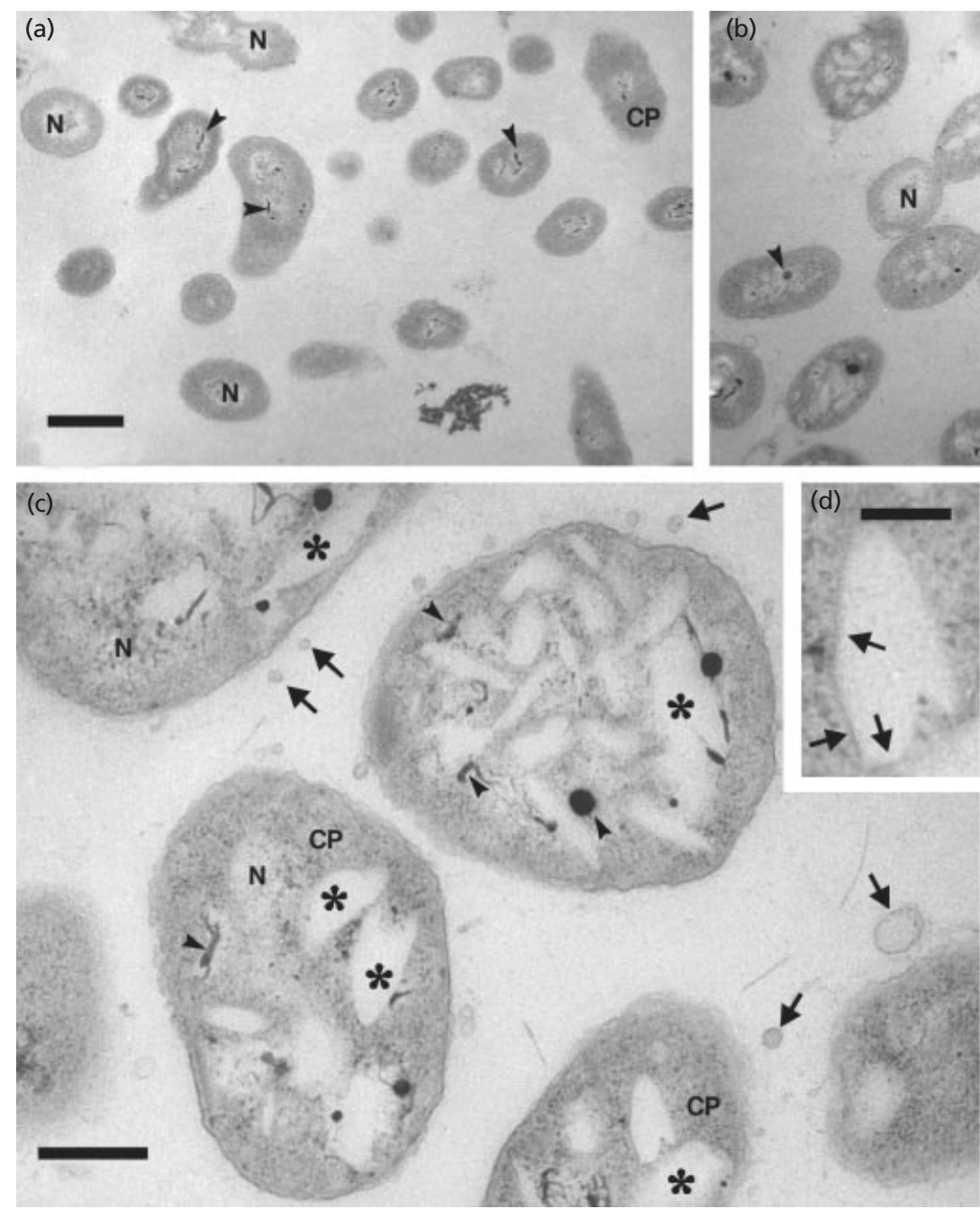
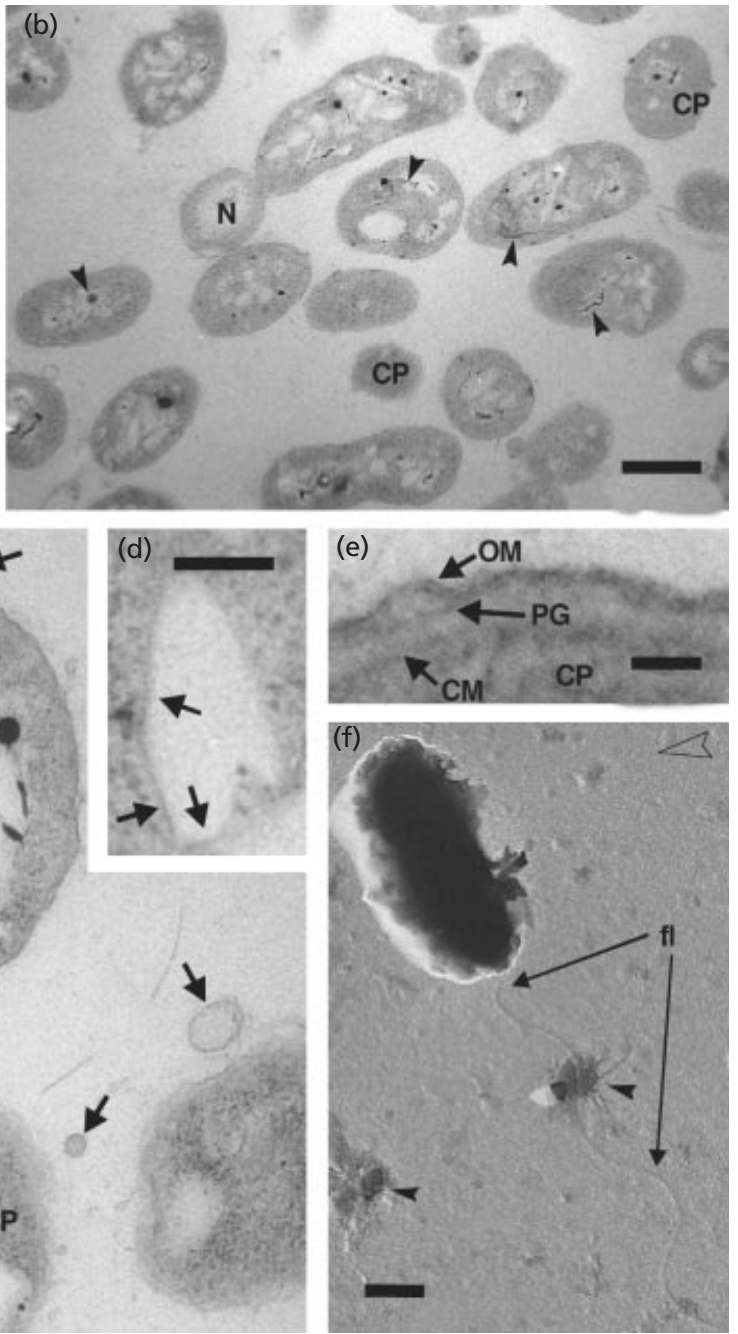

Fig. 1. Ultrastructural analysis of mid-exponentially growing cells of isolate $M E 102^{\top}$. (a)-(d) Representative views of ultrathin-sectioned, rod-like cells from the water phase (a) and the oil phase (b) (bars, $1 \cdot 1 \mu \mathrm{m})$. 'Oil' cells are shown in detail (c) (bar, $300 \mathrm{~nm}$ ). N, Nucleoid; CP, cytoplasm. Electron-dense deposits of spherical or filigran shape are present in the cytoplasm of both cell types (arrowheads). Besides the difference in size, the oil-associated cells characteristically contain many irregularly shaped inclusions (c, asterisks), which show distinct crystallinity because of straight edges and edge angles (d, arrows; bar, $135 \mathrm{~nm}$ ). (e) The outer membrane of the cell wall (OM) and the peptidoglycan (PG) enclose the cytoplasm (CP), surrounded by cytoplasmic membrane (CM) (bar, $40 \mathrm{~nm}$ ). (f) A shadow-cast 'water' cell shows its single flagellum $(\mathrm{fl})$ at the cell pole (bar, $600 \mathrm{~nm}$ ). Artefacts from air-dried constituents of the growth medium (large arrowheads) and the shadowing direction (open arrowhead) are indicated.

$n$-alkane enrichment to solid SM1 medium. Based on phase-contrast microscopy, several morphologically distinct forms were identified. 16S rRNA gene sequencing of single isolates showed that they all belonged to the $\gamma$-Proteobacteria (Table 1), particularly the genera Alcanivorax and Marinobacter. One of the isolates, ME102 ${ }^{\mathrm{T}}$, appeared to be phylogenetically distinct and was selected for more detailed analysis.

\section{Phenotypic characteristics}

Isolate $\mathrm{ME} 102^{\mathrm{T}}$ used aliphatic hydrocarbons as principal carbon and energy sources. In liquid media, cells colonized the surface of alkane droplets and grew in a dense film on this hydrophobic substrate, although some cells were detectable in an aqueous phase. The organism grew in both liquid and solid media supplemented with aliphatic hydrocarbons with alkyl chain lengths between $\mathrm{C}_{11}$ and $\mathrm{C}_{20}$. The oxidized derivatives of these $n$-alkanes, i.e. alkanoles and alkanoates, were also utilized by the organism, as well as some other compounds possessing hydrocarbon chains, e.g. Tweens 40 and 80 . However, none of the other compounds listed in Methods was taken up and utilized by this bacterium. The organism was mesophilic, with an optimum growth temperature of about 25-30 ${ }^{\circ} \mathrm{C}$; minimum and maximum temperatures for growth were 10 and $37^{\circ} \mathrm{C}$. Growth occurred at $\mathrm{NaCl}$ concentrations of $0.06-10.50 \%(\mathrm{w} / \mathrm{v})$, with an optimum between 2.5 and $5.0 \% \mathrm{NaCl}$. Cells stained 


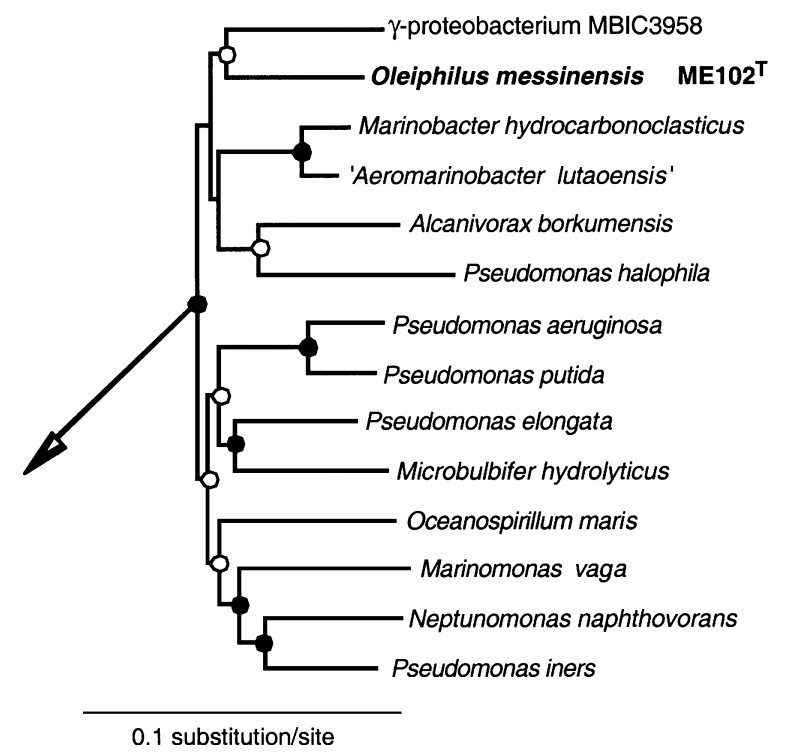

Fig. 2. Position of Oleiphilus messinensis $M E 102^{\top}$ among the closest related representatives of $\gamma$-Proteobacteria based on $16 \mathrm{~S}$ rRNA phylogenetic analysis. Symbols at nodes: 0 , bootstrap values $>80 \%$; $O$, bootstrap values between 60 and $80 \%$; no symbol, bootstrap values $<60 \%$. Pirellula marina ATCC $49069^{\top}$ (X62912) was used as the root organism. See Methods for reference organisms and accession numbers.

Gram-negative and were motile short rods. Other phenotypic properties are listed in Table 2 .

\section{Ultrastructural analysis}

Under the experimental conditions used, isolate $M E 102^{\mathrm{T}}$ grew in an aqueous emulsion of oil/water, where two physiologically diverse cell fractions were obtained (Fig. 1), those in the water phase and those in contact with the oil droplets. Ultrastructural analysis of cells from the water phase showed the general bacterial morphology with a central chromosome, surrounded by a homogeneous cytoplasm. Often the nucleoid and cytoplasm (Fig. 1a-c) were interspersed with irregularly shaped, filigran to spheric, electrondense matter, irrespective of growth in the water or oil phase (Fig. 1a-c), which may represent polyphosphatic condensation products. The cell wall was of the Gramnegative type (Fig. 1e), based on the presence of an outer membrane and a faint peptidoglycan layer within the periplasm. Cells were motile by the aid of a single, polarly situated flagellum (Fig. 1f).

Three distinct morphological differences between water- and oil-phase-grown cells were observed. (i) In general, the diameter of 'oil' cells (Fig. 1b) was larger (mean diameter $1.07 \pm 0.19 \mu \mathrm{m}, n=13$; max., $1.39 \mu \mathrm{m}$; min., $0.66 \mu \mathrm{m})$ relative to the 'water' cells (Fig. 1a) (mean diameter $0 \cdot 77 \pm 0 \cdot 11 \mu \mathrm{m}, n=13$; $\max ., 0.95 \mu \mathrm{m}$; min., $0 \cdot 66 \mu \mathrm{m}$ ). (ii) 'Oil' cells contained large numbers of irregularly shaped, electron-translucent inclusions (Fig. 1c, asterisks), which were often outlined by sharp edges and edge-angles characteristic of crystalline inclusions (Fig. 1d, arrows). These inclusions can make up to $50 \%$ or more of the total cell volume, as suggested by observations of randomly selected crosssectioned cells (Fig. 1c). (iii) 'Oil' cells were typically surrounded by electron-translucent membrane vesicles, obviously produced by blebbing events of the outer membrane (Fig. 1c, arrows).

\section{Molecular phylogenetic analysis}

Initial similarity matrix analysis of the full-length $16 \mathrm{~S}$ rDNA sequence of isolate ME102 ${ }^{\mathrm{T}}$ (Maidak et al., 1997) showed that this organism was a member of the $\gamma$-Proteobacteria. However, the sequence similarity to its closest relatives from the genera Marinobacter, Alcanivorax and an unidentified isolate, MBIC3958, did not exceed 0.91. Furthermore, strain ME102 represented a deep lineage and did not possess close phylogenetic relatives within the marine $\gamma$-Proteobacteria (Fig. 2) or the principal lineages of the $\gamma$ Proteobacteria (Fig. 3) (Anzai et al., 2000; Maidak et

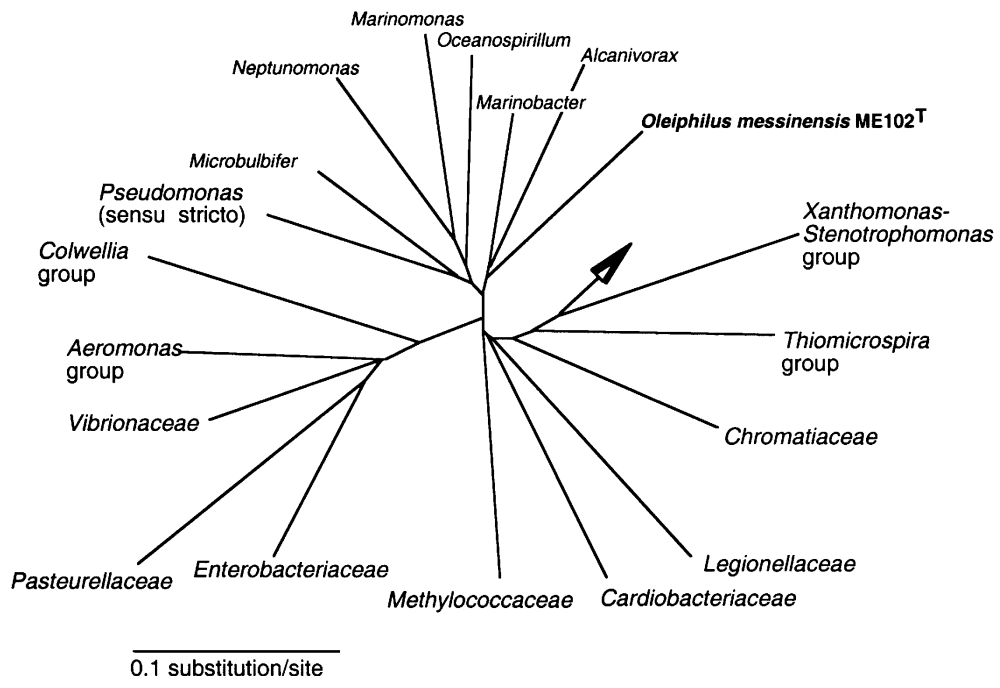

Fig. 3. Position of Oleiphilus messinensis ME102 ${ }^{\top}$ among the principal taxa of the $\gamma$ Proteobacteria based on 165 rRNA phylogenetic analysis. Pirellula marina ATCC 49069 ${ }^{\top}$ (X62912) was used as the root organism. See Methods for reference organisms and accession numbers. 

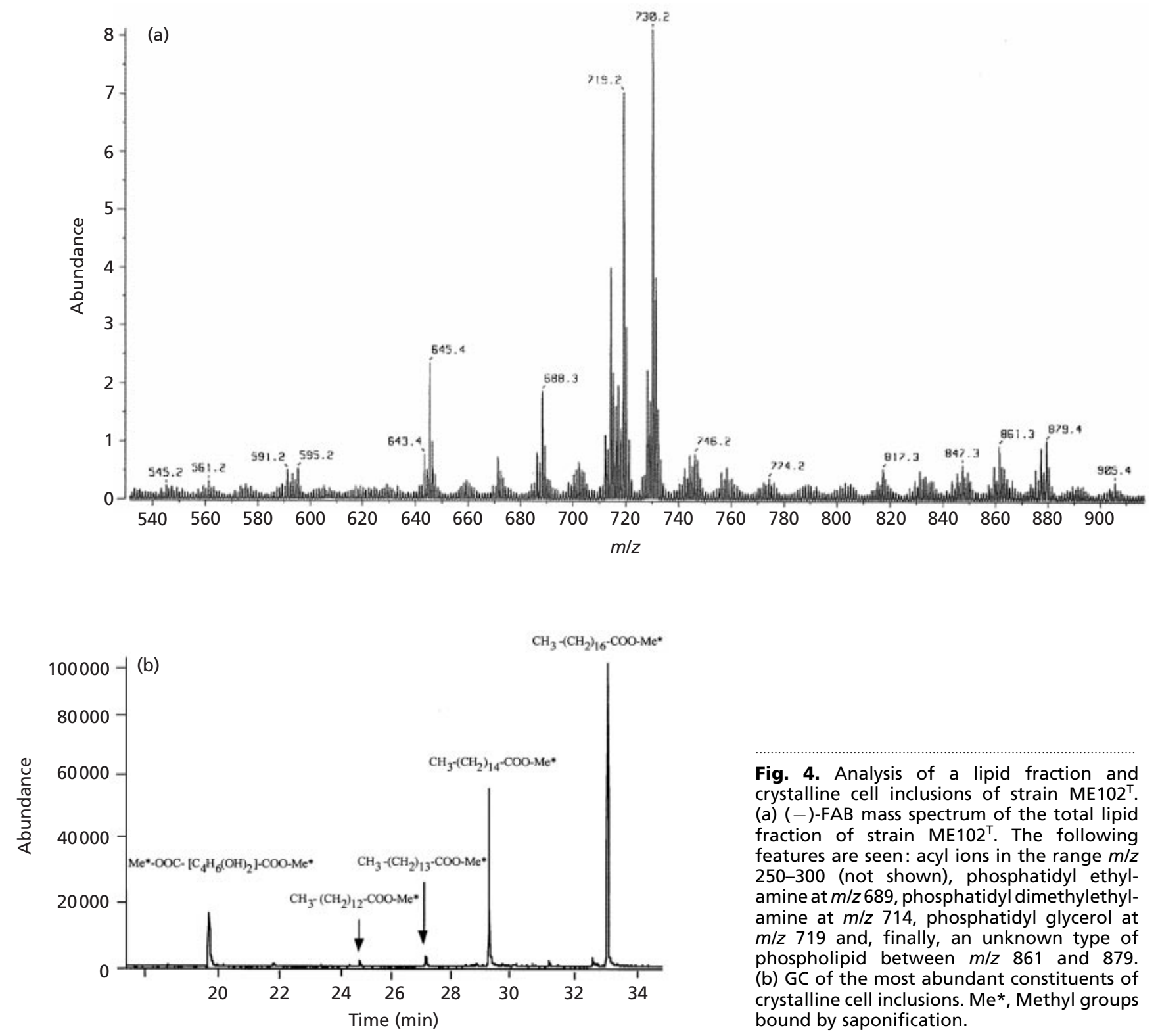

Fig. 4. Analysis of a lipid fraction and crystalline cell inclusions of strain ME102 ${ }^{\top}$. (a) (-)-FAB mass spectrum of the total lipid fraction of strain $M E 102^{\top}$. The following features are seen: acyl ions in the range $\mathrm{m} / \mathrm{z}$ 250-300 (not shown), phosphatidyl ethylamine at $m / z 689$, phosphatidyl dimethylethylamine at $\mathrm{m} / \mathrm{z}$ 714, phosphatidyl glycerol at $\mathrm{m} / \mathrm{z} 719$ and, finally, an unknown type of phospholipid between $\mathrm{m} / \mathrm{z} 861$ and 879 . (b) GC of the most abundant constituents of crystalline cell inclusions. Me*, Methyl groups bound by saponification.

al., 1997; Van de Peer et al., 1996). For this analysis, regions of uncertain alignment and hypervariable regions of sequences were eliminated (Anzai et al., 2000).

\section{Lipid analysis}

Four different types of polar lipid were detected, phosphatidyl glycerol, phosphatidyl ethylamine, phosphatidyl dimethylethylamine and lipids belonging to an unknown type of phospholipid (Fig. 4a; Table 3 ). Because ions of GPAs with various $m / z$ were formed from one parent ion, as in the case of $m / z 714$, isobaric species due to the presence of different fatty acids were present (Table 3). A group of molecular ions between $m / z 861$ and 879 was observed that could not be attributed to known polar lipids. Their CID
Table 3. Polar lipids identified in a cell extract of strain ME102

PG, Phosphatidyl glycerol; PE, phosphatidyl ethylamine; DME, phosphatidyl dimethylethylamine; Unknown, unknown phosphatidyl lipid.

\begin{tabular}{|llcc|}
\hline Mass & Lipid type & $\mathbf{R}_{\mathbf{1}}$-COOH $(\boldsymbol{s n}-\mathbf{1})$ & $\mathbf{R}_{\mathbf{2}}$-COOH (sn-2) \\
\hline 689 & PE & $16: 1$ & $16: 0$ \\
689 & PE & $16: 0$ & $16: 1$ \\
714 & DME & $16: 1$ & $16: 1$ \\
714 & DME & $16: 0$ & $16: 2$ \\
719 & PG & $16: 0$ & $16: 1$ \\
861 & Unknown & $18: 1$ & $16: 0$ \\
861 & Unknown & $18: 0$ & $16: 1$ \\
879 & Unknown & $16: 0$ & $16: 1$ \\
\hline
\end{tabular}


Table 4. Comparison of PLFA compositions of Oleiphilus messinensis $\mathrm{ME} 102^{\top}$ and related marine $\gamma$-Proteobacteria

Data were from this study or from Yakimov et al. (1998) (Alcanivorax borkumensis) and Huu et al. (1999) (Marinobacter spp.).

\begin{tabular}{|c|c|c|c|c|}
\hline Fatty acid & $\begin{array}{c}\text { Oleiphilus } \\
\text { messinensis } \text { ME102 }^{\mathrm{T}}\end{array}$ & $\begin{array}{c}\text { Alcanivorax } \\
\text { borkumensis } \mathrm{SK2}^{\mathrm{T}}\end{array}$ & $\begin{array}{c}\text { Marinobacter } \\
\text { hydrocarbonoclasticus }\end{array}$ & $\begin{array}{c}\text { Marinobacter } \\
\text { aquaeolei } \mathrm{VT}^{\mathrm{T}}\end{array}$ \\
\hline $\mathrm{C} 14: 0$ & $5 \cdot 5$ & $1 \cdot 1$ & $2 \cdot 2$ & $2 \cdot 6$ \\
\hline $\mathrm{C} 15: 0$ & $4 \cdot 1$ & $0 \cdot 1$ & $1 \cdot 4$ & $2 \cdot 2$ \\
\hline isoC16: $1 \omega 8$ & $3 \cdot 2$ & - & - & - \\
\hline $\mathrm{C} 16: 1 \omega 9$ & $10 \cdot 9$ & $7 \cdot 1$ & $8 \cdot 5$ & $11 \cdot 6$ \\
\hline $\mathrm{C} 16: 1 \omega 7$ & $16 \cdot 6$ & $10 \cdot 1$ & $8 \cdot 3$ & $6 \cdot 8$ \\
\hline $\mathrm{C} 16: 0$ & 38.6 & $31 \cdot 5$ & $23 \cdot 6$ & $23 \cdot 2$ \\
\hline $\mathrm{C} 17: 0$ & $1 \cdot 4$ & $0 \cdot 1$ & $3 \cdot 4$ & $3 \cdot 8$ \\
\hline $\mathrm{C} 18: 1 \omega 9$ & $1 \cdot 4$ & $47 \cdot 1$ & $29 \cdot 4$ & $19 \cdot 8$ \\
\hline $\mathrm{C} 18: 0$ & $7 \cdot 7$ & $0 \cdot 2$ & 1.9 & $1 \cdot 4$ \\
\hline $\mathrm{C} 20: 1 \omega 9$ & $1 \cdot 3$ & - & - & - \\
\hline $\begin{array}{l}\text { Percentage of detected } \\
\text { PLFA identified }\end{array}$ & $90 \cdot 7$ & $97 \cdot 3$ & $78 \cdot 7$ & $71 \cdot 5$ \\
\hline
\end{tabular}

spectra showed the formation of GPA ions, identifying these polar lipids as phospholipids. Another abundant ion at $\mathrm{m} / \mathrm{z} 730$ was a fragment formed from the unknown lipid of $m / z 879$, as observed in the CID-MS of the latter ion (data not shown). Analysis of the GPAs revealed the fatty acids and their relative position on the glycerol backbone of these unknown phospholipids. Further studies are under way to identify these lipids, which may be glycophospholipids.

After saponification of phospholipids, ten major fatty acids were detected in strain ME102 ${ }^{\mathrm{T}}$ (Table 4). The saturated fatty acids $\mathrm{C}_{14}-\mathrm{C}_{18}$ represented more than $57 \%$ of the total extracted PLFA and palmitate was a major PLFA compound.

\section{Analysis of the crystalline inclusions}

The crystalline inclusions in the cells grown in direct contact with droplets of $n$-hexadecane $\left(\mathrm{C}_{16} \mathrm{H}_{34}\right)$ consisted of three major compounds (Fig. 4b): palmitic acid, $\mathrm{C}_{15} \mathrm{H}_{31} \mathrm{COOH}$ (about 33\%); stearic acid, $\mathrm{C}_{17} \mathrm{H}_{35} \mathrm{COOH}$ (about 55\%); and dihydroxy-butanedicarboxylic acid, HOOC- $\left[\mathrm{C}_{4} \mathrm{H}_{6}(\mathrm{OH})_{2}\right]-\mathrm{COOH}$ (up to $10 \%)$. Other compounds were also detected in small quantities (up to 5\%), e.g. myristic acid $\left(\mathrm{C}_{13} \mathrm{H}_{27} \mathrm{COOH}\right)$ and pentadecanoic acid $\left(\mathrm{C}_{14} \mathrm{H}_{29} \mathrm{COOH}\right)$. To control possible contamination of crystalline inclusions with membrane lipids, the chloroform extract was additionally analysed using (-)-FAB-MS and showed only a few ions at low intensity. At the same time, no ions were observed for lipids extracted by the Bligh-Dyer procedure, suggesting that no crystalline inclusions were present in the fatty acid methyl esters of the polar lipids either.

A possible explanation for the accumulation of the crystalline inclusions is that the media ONR7a and
SM1 used to grow strain ME102 ${ }^{\mathrm{T}}$ are very limited in nitrogen. Whereas $n$-hexadecane was normally present at $1.5 \%(\mathrm{v} / \mathrm{v})$, which corresponds to $9 \cdot 9 \mathrm{~g}$ carbon $^{-1}$, nitrogen (in the form of ammonium chloride, $0.27 \mathrm{~g} \mathrm{l}^{-1}$ ) was present at $0.07 \mathrm{~g} \mathrm{l}^{-1}$. This is far below the $\mathrm{C} / \mathrm{N}$ ratio necessary for balanced growth, which varies slightly in bacteria around 5:1 (Battley, 1987). After transfer of cells pre-grown under such conditions, and harbouring crystalline inclusions, into fresh ONR7a medium, additionally supplemented with ammonium chloride $\left(8 \mathrm{~g} \mathrm{l}^{-1}\right.$, i.e. $2 \cdot 1 \mathrm{~g}$ nitrogen $1^{-1}$ ) and incubated for $24 \mathrm{~h}$, these inclusions disappeared, as observed by phase-contrast and electron microscopy. The ultrastructure of cells treated this way was very similar to that shown in Fig. $1(\mathrm{a})$.

\section{$\mathbf{G}+\mathbf{C}$ content of DNA}

The $\mathrm{G}+\mathrm{C}$ content of the DNA of $\mathrm{ME} 102^{\mathrm{T}}$ was $49.0 \mathrm{~mol} \%$, which is comparable to that of Alcanivorax borkumensis and Marinobacter spp. (Table 2).

\section{Genome format}

PFGE analysis of endonuclease digests of the genomic DNA of isolate ME102 $2^{\mathrm{T}}$ indicated that the size of the genome was about $2 \cdot 3 \mathrm{Mbp}$. No plasmids were visualized.

\section{Alkane hydroxylase gene (alkB)}

The putative gene for alkane hydroxylase, the key enzyme of alkane catabolism, was cloned using the approach of Smits et al. (1999). Phylogenetic analysis of the deduced amino acid sequence coded by this gene 


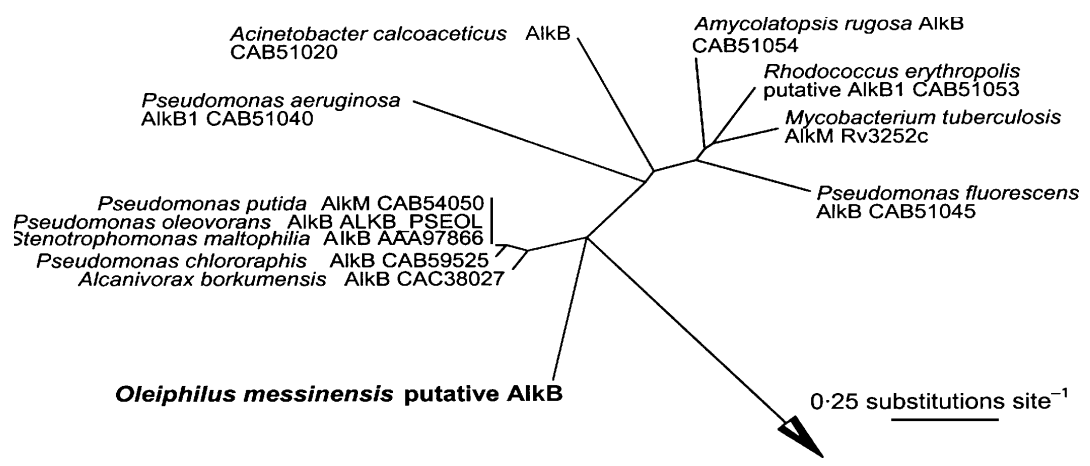

Fig. 5. Phylogenetic position of protein sequence for the cloned putative alkane hydroxylase from strain ME102 ${ }^{\top}$. Bar, 0.25 substitutions per amino acid position. SWISS_PROT accession numbers are shown.

is shown in Fig. 5. The protein sequence possessed just $60 \%$ sequence identity to the most closely related enzymes, AlkB from Pseudomonas oleovorans and Alcanivorax borkumensis.

\section{DISCUSSION}

On the basis of the results of phenotypic analyses, the marine environment as a source of isolation, the restricted nutritional profile, the absence of fermentative metabolism and the $\mathrm{G}+\mathrm{C}$ content, isolate ME102 ${ }^{\mathrm{T}}$ shares many traits with the genera Alcanivorax (Yakimov et al., 1998) and Marinobacter (Gauthier et al., 1992) (Table 2), all of which represent a group of Gram-negative marine species with respiratory metabolism. The above genera, however, have greater nutritional versatility. In contrast, ME102 ${ }^{\mathrm{T}}$ exhibits an extremely narrow spectrum of substrates that support growth. Isolate ME $102^{\mathrm{T}}$ utilizes only $n$ alkanes, alkane alcohols and alkanoates with a chain length between $\mathrm{C}_{11}$ and $\mathrm{C}_{20}$. This phenotype is similar to that of Alcanivorax borkumensis, another bacterium with a highly restricted substrate range for alkanes. However, the latter organism is also able to utilize two 'simple' substrates, pyruvate and acetate. Another characteristic feature of isolate ME102 ${ }^{\mathrm{T}}$ is the largescale accumulation of crystals of alkanoates when cells are grown under nitrogen-limiting conditions, in direct contact with alkane droplets or grown on solid medium ONR7a, which contains only small quantities of mineral nitrogen.

The PLFA profile of strain ME102 ${ }^{\mathrm{T}}$ was dissimilar from the profiles of closely related hydrocarbondegrading micro-organisms. The most abundant fatty acid in ME102 $2^{\mathrm{T}}$ was palmitic ( $n$-hexadecanoic) acid, whereas oleic (9-octadecenoic) acid is the main PLFA component in other phylogenetically closely affiliated micro-organisms. The PLFA composition of strain ME102 ${ }^{\mathrm{T}}$ was most similar to those of Alcanivorax borkumensis and Marinobacter hydrocarbonoclasticus.

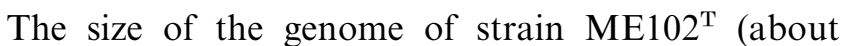
$2.3 \mathrm{Mbp}$ ) is similar to the genome size of some oligotrophic $\gamma$-Proteobacteria, such as Alcanivorax borkumensis $\mathrm{SK} 2^{\mathrm{T}}$ and Cycloclasticus oligotrophus $(3 \cdot 0$ and 2.0 Mbp, respectively; Button et al., 1998), autotrophic Acidithiobacillus ferrooxidans (about 2.9 Mbp) and pathogenic bacteria Haemophilus spp. (1.8 Mbp) and Pasteurella spp. (2.4 Mbp). It has a much smaller genome than Pseudomonas aeruginosa, Pseudomonas putida, Pseudomonas fluorescens, Xanthomonas spp., Escherichia coli, Yersinia spp. and Vibrio spp. (respectively $6 \cdot 3,6 \cdot 1,5 \cdot 5,5 \cdot 1,4 \cdot 6-5 \cdot 6,4 \cdot 3-4 \cdot 7$ and 3.8-4.0 Mbp; TIGR Microbial Databases, http:// www.tigr.org/tdb/). The smaller genome correlates with the lower metabolic versatility of strain ME102 ${ }^{\mathrm{T}}$.

Analysis of the 16S rRNA gene sequence enabled an estimation of the phylogenetic position of the isolated strain: this organism is affiliated with the $\gamma$ Proteobacteria. Comparison to representatives of principal taxa of this group of organisms (Fig. 3) showed that this organism forms a deep branch close to the Marinobacter and Alcanivorax groups and the Pseudomonadaceae, with about $91 \%$ 16S rDNA sequence identity or less.

It is apparent from the phenotypic properties and the differences in 16S rRNA gene sequences that the hydrocarbon-degrading strain isolated from marine samples from the harbour of Messina (Sicily) cannot be assigned to any previously recognized bacterial family or genus and thus can be described as a novel species within a new genus, Oleiphilus messinensis gen. nov., sp. nov., in a new family, Oleiphilaceae fam. nov.

\section{Description of Oleiphilaceae fam. nov.}

Oleiphilaceae (O.le.i'phi.la'ce.ae. N.L. n. Oleiphilus the type genus of the family; -aceae ending to denote family; N.L. neut. pl. n. Oleiphilaceae the Oleiphilus family).

The type and only genus is Oleiphilus.

\section{Description of Oleiphilus gen. nov.}

Oleiphilus (O.le.i'phi.lus. L. n. oleum oil; Gr. adj. philos loving; N.L. n. Oleiphilus oil-loving organism). Gram-negative, motile, aerobic thick rods that are generally $0.7-1.4 \mu \mathrm{m}$ wide and $1.5-2.0 \mu \mathrm{m}$ long when growing in medium supplemented with $n$-hexadecane. Only aliphatic hydrocarbons and their derivatives are used as carbon sources for growth. Oxidase- and catalase-positive. The genome size is about $2 \cdot 3 \mathrm{Mbp}$. The DNA G + C content is $49 \cdot 0 \mathrm{~mol} \%$. The type and only species is Oleiphilus messinensis. 


\section{Description of Oleiphilus messinensis sp. nov.}

Oleiphilus messinensis (mes.si.nen'sis. L. adj. messinensis pertaining to Messina, the city in Sicily where the organism was isolated).

Motile, polar monotrichous, aerobic rods. Cells growing on $n$-hexadecane droplets accumulate crystalline inclusions consisting of $n$-hexadecanoate and $n$ octanoate; these can make up over $50 \%$ of the cell volume at late growth phases. Grows at temperatures of $10-37{ }^{\circ} \mathrm{C}$, with optimal growth between 25 and $30{ }^{\circ} \mathrm{C}$. Growth occurs at $\mathrm{NaCl}$ concentrations of $0.06-10.5 \%(\mathrm{w} / \mathrm{v})$, with an optimum between 2.5 and $5 \%$. Exhibits Tweenase activity, but not agarase, amylase, arginine dihydrolase, ornithine decarboxylase, lysine decarboxylase, gelatinase or aesculinase activities. Nitrate is reduced to nitrite. Aliphatic hydrocarbons and their derivatives, with chain lengths between $\mathrm{C}_{11}$ and $\mathrm{C}_{20}$, are the only substrates that support growth. Principal fatty acids in the PLFA profile are 16:0 and 16:1. The DNA G+C content is $49.0 \mathrm{~mol} \%$. According to the 16S rRNA gene sequence, this bacterium belongs to the $\gamma$-Proteobacteria and occupies a distinct position neighbouring the genera Alcanivorax and Marinobacter. The type and only strain is $\mathrm{ME} 102^{\mathrm{T}}\left(=\mathrm{DSM} \quad 13489^{\mathrm{T}}=\mathrm{LMG}\right.$ $\left.20357^{\mathrm{T}}\right)$.

\section{ACKNOWLEDGEMENTS}

We are indebted to Peter Wolff for assistance in fatty acid analysis, Carsten Strompl for sampling assistance and Ruprecht Christ for measuring the CID mass spectra. This work was supported by grants from the German Federal Ministry for Science, Education and Research (Project no. 0319433C) and NATO-Linkage Grant LST.CLG.975776. K.N.T. gratefully acknowledges the generous support of the Fonds der Chemischen Industrie. We thank Hans Trüper (University of Bonn) for advice and corrections of Latin names and William Whitman for his comments and remarks that significantly improved the manuscript.

\section{REFERENCES}

Abraham, W.-R., Meyer, H., Lindholst, S., Vancanneyt, M. \& Smit, J. (1997). Phospho- and sulfolipids as biomarkers of Caulobacter, Brevundimonas and Hyphomonas. Syst Appl Microbiol 20, 522-539.

Altschul, S. F., Madden, T. L., Schaffer, A. A., Zhang, J., Zhang, Z., Miller, W. \& Lipman, D. J. (1997). Gapped BLAST and PSI-BLAST: a new generation of protein database search programs. Nucleic Acids Res 25, 3389-3402.

Anzai, Y., Kim, H., Park, J.-Y., Wakabayashi, H. \& Oyaizu, H. (2000). Phylogenetic affiliation of the pseudomonads based on $16 \mathrm{~S}$ rRNA sequence. Int J Syst Evol Microbiol 50, 1563-1589.

Battley, E. H. (1987). Energetics of Microbial Growth. New York: Wiley.

Baumann, P. \& Baumann, L. (1981). The marine Gram-negative eubacteria; genera Photobacterium, Beneckea, Alteromonas, Pseudomonas, and Alcaligenes. In The Prokaryotes, pp. 1302-1330. Edited by M. P. Starr, H. Stolp, H. G. Trüper, A. Balows \& H. G. Schlegel. Berlin: Springer.

Bligh, E. G. \& Dyer, W. J. (1959). A rapid method for total lipid extraction and purification. Can J Biochem Physiol 37, 911-917.
Button, D. K., Robertson, B. R., Lepp, P. W. \& Schmidt, T. M. (1998). A small, dilute-cytoplasm, high-affinity, novel bacterium isolated by extinction culture and having kinetic constants compatible with growth at ambient concentrations of dissolved nutrients in seawater. Appl Environ Microbiol 64, 4467-4476.

Dyksterhouse, S. E., Gray, J. P., Herwig, R. P., Lara, J. C. \& Staley, J. T. (1995). Cycloclasticus pugetii gen. nov., sp. nov., an aromatic hydrocarbon-degrading bacterium from marine sediments. Int $J$ Syst Bacteriol 45, 116-123.

Felsenstein, J. (1993). PHYLIP (phylogenetic inference package), version 3.5c. Department of Genetics, University of Washington. Seattle: WA, USA.

Gauthier, M. J., Lafay, B., Christen, R., Fernandez, L., Acquaviva, M., Bonin, P. \& Bertrand, J. C. (1992). Marinobacter hydrocarbonoclasticus gen. nov., sp. nov., a new, extremely halotolerant, hydrocarbon-degrading marine bacterium. Int J Syst Bacteriol 42, 568-576.

Golyshina, O. V., Pivovarova, T. A., Karavaiko, G. I. \& 7 other authors (2000). Ferroplasma acidiphilum gen. nov., sp. nov., an acidophilic, autotrophic, ferrous-iron-oxidizing, cell-wall-lacking, mesophilic member of the Ferroplasmaceae fam. nov., comprising a distinct lineage of the Archaea. Int J Syst Evol Microbiol 50, 997-1006.

Harayama, S., Kishira, H., Kasai, Y. \& Shutsubo, K. (1999). Petroleum biodegradation in marine environments. J Mol Microbiol Biotechnol 1, 63-70.

Hedlund, B. P., Geiselbrecht, A. D., Bair, T. J. \& Staley, J. T. (1999). Polycyclic aromatic hydrocarbon degradation by a new marine bacterium, Neptunomonas naphthovorans gen. nov., sp. nov. Appl Environ Microbiol 65, 251-259.

Heller, D. N., Murphy, C. M., Cotter, R. J., Fenselau, C. \& Uy, O. M. (1988). Constant neutral loss scanning for the characterization of bacterial phospholipids desorbed by fast atom bombardment. Anal Chem 60, 2787-2791.

Huu, N. B., Denner, E. B., Ha, D. T., Wanner, G. \& Stan-Lotter, H. (1999). Marinobacter aquaeolei sp. nov., a halophilic bacterium isolated from a Vietnamese oil-producing well. Int J Syst Bacteriol 49, 367-375.

Maidak, B. L., Olsen, G. J., Larsen, N., Overbeek, R., McCaughey, M. J. \& Woese, C. R. (1997). The RDP (Ribosomal Database Project). Nucleic Acids Res 25, 109-111.

Mesbah, M., Premachandran, U. \& Whitman, W. B. (1989). Precise measurement of the $\mathrm{G}+\mathrm{C}$ content of deoxyribonucleic acid by highperformance liquid chromatography. Int J Syst Bacteriol 39, 159-167.

Murphy, R. C. \& Harrison, K. A. (1994). Fast atom bombardment mass spectrometry of phospholipids. Mass Spectrom Rev 13, 57-75.

Passeri, A., Schmidt, M., Haffner, T., Wray, V., Lang, S. \& Wagner, F. (1992). Marine biosurfactants. IV. Production, characterization and biosynthesis of an anionic glucose lipid from marine bacterial strain MM1. Appl Microbiol Biotechnol 37, 281-286.

Rambaut A. (1996). Se-Al (Sequence Alignment Editor) version 1.0 alpha 1 . Distributed by the author (http://evolve. zoo. ox. ac. uk/SeA1/Se-A1.html). Department of Zoology, University of Oxford, Oxford, UK.

Shizuya, H., Birren, B., Kim, U.-J., Mancino, V., Slepak, T., Tachiiri, Y. \& Simon, M. (1992). Cloning and stable maintenance of 300kilobase-pair fragments of human DNA in Escherichia coli using an Ffactor-based vector. Proc Natl Acad Sci U S A 89, 8794-8797.

Smibert, R. M. \& Krieg, N. R. (1981). General characterization. In Manual of Methods for General Bacteriology, pp. 409-443. Edited by P. Gerhardt, R. G. E. Murray, R. N. Costilow, E. W. Nester, W. A. Wood, N. R. Krieg \& G. B. Phillips. . Washington, DC: American Society for Microbiology.

Smits, T. H. M., Rothlisberger, M., Witholt, B. \& van Beilen, J. B. (1999). Molecular screening for alkane hydroxylase genes in Gramnegative and Gram-positive strains. Environ Microbiol 1, 307-317.

Tamaoka, J. \& Komagata, K. (1984). Determination of DNA base composition by reversed-phase high-performance liquid chromatography. FEMS Microbiol Lett 25, 125-128.

Vancanneyt, M., Witt, S., Abraham, W.-R., Kersters, K. \& 
Fredrickson, H. L. (1996). Fatty acid content in whole-cell hydrolysates and phospholipid fractions of pseudomonads: a taxonomic evaluation. Syst Appl Microbiol 19, 528-540.

Van de Peer, Y., Chapelle, S. \& De Wachter, R. (1996). A quantitative map of nucleotide substitution rates in bacterial rRNA. Nucleic Acids Res 24, 3381-3391.

Wilson, K. (1987). Preparation of genomic DNA from bacteria, pp.
2.4.1-2.4.2. In Current Protocols in Molecular Biology. Edited by F. M. Ausubel, R. Brent, R. E. Kingston, D. D. Moore, J. G. Seidman, J. A. Smith \& K. Struhl. New York: Wiley.

Yakimov, M. M., Golyshin, P. N., Lang, S., Moore, E. R., Abraham, W.-R., Lunsdorf, H. \& Timmis, K. N. (1998). Alcanivorax borkumensis gen. nov., sp. nov., a new, hydrocarbon-degrading and surfactantproducing marine bacterium. Int $J$ Syst Bacteriol 48, 339-348. 